\title{
Tourist Preference Towards Dark Tourism Attraction (A Case Study of Kelud Mountain)
}

\author{
Jili Anggraita Sari \\ Student, Department of Urban and Regional Planning \\ Engineering Faculty, Brawijaya University \\ Malang, Indonesia
}

\author{
Turniningtyas Ayu R \\ Lecturer,Department of Urban and Regional Planning \\ Engineering Faculty, Brawijaya University \\ Malang, Indonesia
}

\author{
Fadly Usman \\ Lecturer,Department of Urban and Regional Planning \\ Engineering Faculty, Brawijaya University \\ Malang, Indonesia
}

\begin{abstract}
Dark tourism is one of the new themes in the industry of tourism. One of the ways is utilizing disaster tourism sites to attract visitors. Dark tourism can be an income alternative for the local people who live near the sites. Kelud Mountain in Kediri Regency is one of the examples of dark tourism destinations where visitors swarm it. It is an active volcano with its last eruption in the past six years. Before eruption there was a phenomenal tourist attraction named "Anak Gunung Kelud", but now after eruption the crater of Kelud mountain is main attraction in location. Every day especially on the weekend there are many visitors come to location, so it is essential to find out the elements in tourism as an attraction for visitors using konjoin analysis.
\end{abstract}

Keywords:- Dark Tourism, Tourist,Environmental.

\section{INTRODUCTION}

In general, a disaster is an event that brings destruction and damage to the environment [1]. Indonesia lies between two continents and two oceans, as well as the active plates that make the country prone to disasters include tsunami, earthquake, flood, landslide, and eruption [1]. One of the most common natural disasters happens in Indonesia is eruption [2]. Volcanic eruption in Indonesia has caused losses to include its economy, society, and environment, as well as dead victims [2]. Even though volcanic eruption in this country has impacts on the economy and other aspects, this kind of natural disaster has been showing improving economic effect in the tourism industry as time goes by [2] Several examples of dark tourism sites where a lot of visitors come to visit are Banda Aceh as the tsunami site and Cangkringan District Yogyakarta for its Merapi Mountain $[11,1]$. The existence of natural disaster history as tourism sites appear because a lot of people are curious to see how those places look like after the deathly event happened $[11,1]$. The destinations that found there actually have severe risk in every activity that people do [15]. The phenomenon when people visit disaster tourism sites is called dark tourism [3,17]. Dark tourism is disaster tourism that people enjoy watching and observing a place where a disaster once happened [3]. There are three typologies to consider a place to be dark tourism attraction: dangerous place, haunted house, and field of death [3].

The meaning of a dangerous place is a place that keeps danger [3]. The risk itself means the effect that can put humans in trouble like death when they do their activities [3]. On the other hand, a haunted house is a building or a place that keeps a mysterious story behind it $[3,17]$. Meanwhile, fields of death is a place that buries a lot of bodies in the mass of death that happened a long time ago $[3,17]$. One of the examples of dark tourism phenomenon in East Java is Kelud Mountain in Kediri Regency [4]. Kelud Mountain is an active volcano with eruption scales frequency 15 years as well as it's also one of the tourism icons of Kediri Regency [5]. Lava dome or "The child of Kelud Mountain" [4]. Another tourist destination that attracts many visitors after the eruption happened in 2014 is the crater of Kelud Mountain [4,5]. The breathtaking view in Kelud Mountain after the erupting is the main attraction for visitors, so it makes this place always has a swarm of people [5].

The beginning of the Kelud Mountain fame among tourists showed up after the eruption in 2007 and the appearance of lava dome as magma obstruction that is called as "The Child of Kelud Mountain" with 100 meters width and 20 meters height [6]. One of the reasons why Kelud Mountain has a lot of visitors is the rare phenomenon where visitors can see lava dome as the eruption obstruction which is the first time in this mountain history [6]. Then, with high enthusiasm from visitors since 2007 to 2014, the tourism manager has been improving its facilities intensively [5]. In 2014, the mountain erupted again and the impact was even worse than the last eruption [4,6]. This 2014 eruption affected its morphology condition including the disappearance of the lava dome which was the main tourists' attraction [6]. But the enthusiasm from visitors after the eruption increased from 300 to 500 people every day $[4,5]$. The return of the crater lake makes the visitors more enthusiastic to see the location themselves and the biggest motivation from visitors to come to Kelud Mountain as the dark tourism is their curiosity how the place looks like after the disaster strike [4]. For visitors who have visited Kelud Mountain before eruption tend to have intentions to visit it 
again after the disaster happened to compare how the place is before and after the horrific catastrophe [4].

The enthusiasm of visitors who came to Kelud Mountain is a portrayal of individual's preference in fulfilling their need of recreation and entertainment [7]. A preference can be depicted as a tendency to pick one thing over another, so it can affect how a person takes the decision later on [8]. In tourism, this preference will determine the visitors' interest to like or dislike a tourism product [8]. There are a lot of preferences that can affect the visit towards the tourist attraction, tourism activities, available transportations and accommodations, and souvenirs [9]. The incredible view of Mount Kelud that has active volcano after eruption is worthy to look at [5]. Some people take photos and stroll around the area of the mountain even though the road isn't that smooth. The remaining of eruption also adds the tourist attraction of Mount Kelud. [5].

This study aims to assess the tourists' preferences who visit Mount Kelud using conjoint analysis to find out the type of tourism product that highly wanted in the location. This tourism product will be the main point of the conclusion about the reasons why a lot of visitors go to this mountain even though they know that it keeps danger that can explode anytime.

\section{METHOD}

\section{A. Conjoint Anaylysis}

The conjoint analysis aims to find out someone's preference towards a specific object that has one or more parts [9]. The main result of conjoint analysis is in forms of goods or services or a particular thing that most correspondents want [9].

\section{The Determination of Attributes}

The attribute referred is the research variables in the location of the study [10]. There are six chosen variables attribute in the conjoint analysis of tourists' preferences include tourist destinations, tourists' activities, transportation, facility accommodation, and souvenirs [9]

\section{$>$ Design a combination of attributes (Stimulli)}

A stimulus or combination of attributes is a group of attributes assessed by respondents in the form of a design of combination products [10]. There are three approaches in designing stimuli of combinations: full profile, pairwise comparison, and trade-off $[9,10]$. This study used the design of combinations using a complete profile method to combine all attributes with the chosen attributes level. The minimum of a combination of attributes or stimuli used this following formula: [10].

$$
\begin{aligned}
& \mathrm{JK}=\mathrm{JT}-\mathrm{JA}+1 \\
& \mathrm{JK}=\text { The total of combination of attributes card } \\
& \text { (stimuli) } \\
& \mathrm{JT}=\text { The total of assessed attributes rating } \\
& \mathrm{JA}=\text { The total evaluated attributes }
\end{aligned}
$$

\section{$>$ Process data}

The process of data is done using SPSS software [9]. The presented data is a form of score rank that means the least stimuli given the highest score based on the total of its stimuli [9]. To process the data to get utility estimate, importance values, and correlations used the following formula $[9,10]$.

$\mu(x)=\sum_{i=1}^{m} \sum_{i=1}^{k} a i j X i j$

$\mu(\mathrm{x})$ : total utillity for every stimulli

$\alpha_{\mathrm{ij}} \quad:$ utility from factor to $\mathrm{i}(\mathrm{i}=1,2, \ldots, \mathrm{m})$ dan level $\mathrm{ke} \mathrm{j}$ $(\mathrm{j}=1,2,3 \ldots, \mathrm{k})$

$k \quad:$ the total of attributes level

$m$ : the total of attributes

$\mathrm{X}_{\mathrm{ij}} \quad: 1$ if the level to $\mathrm{j}$ from attribute to $\mathrm{I}$ happen and 0 if it doesn't happen

The next step is to count the importance values with this following hypothesis:

$H_{0}=$ There is no strong correlation between observed variable and estimated preferences

$H_{1}=$ There is strong correlation between observed variable and estimated preferences

The calculation of the importance values is in this following formula [10]:

$I i=\{\operatorname{maks}($ aij $)-\min ($ aij $)\}$, for every $\mathrm{i}$

$\alpha_{\mathrm{ij}}$ : utility from factor to $\mathrm{i}(\mathrm{i}=1,2, \ldots, \mathrm{m})$ and level to $\mathrm{j}(\mathrm{j}=1$, $2,3 \ldots, \mathrm{k})$

The process of data analysis used SPSS software with overall variables that become the $\mathrm{s}$ attributes and processed with that software [10]. The result of the data processing shows utility value, importance value, and correlation from the combination of attributes or stimulus as the analysis elements $[9,10]$

\section{B. Population dan sample}

The population of Mount Kelud in this study with a total of minimum visitors who came in public holidays in one day visit reached 500 people. Meanwhile, the method of sampling selection used Krejcie and Morgan table with 50 people as the population, then the total sample used in this study is 176 people. 


\section{RESULT DAN DISCUSSION}

Mount Kelud administratively located in Sugihwaras District, under the Kediri Regency government, but geographically located in three regions: Kediri Regency, Blitar, and Malang (Fig 1) [5].

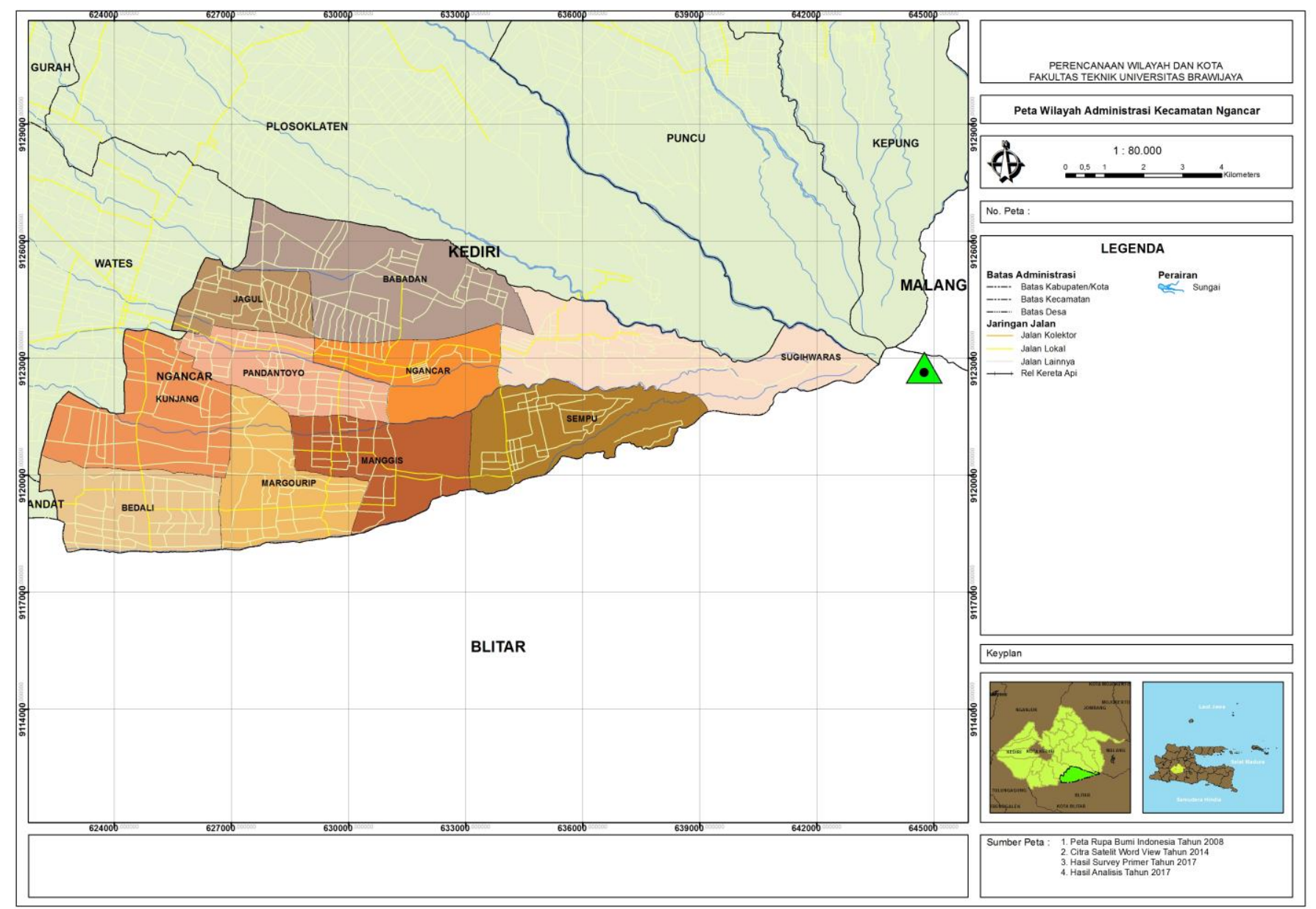

Fig 1:- Research site of Gunung Kelud

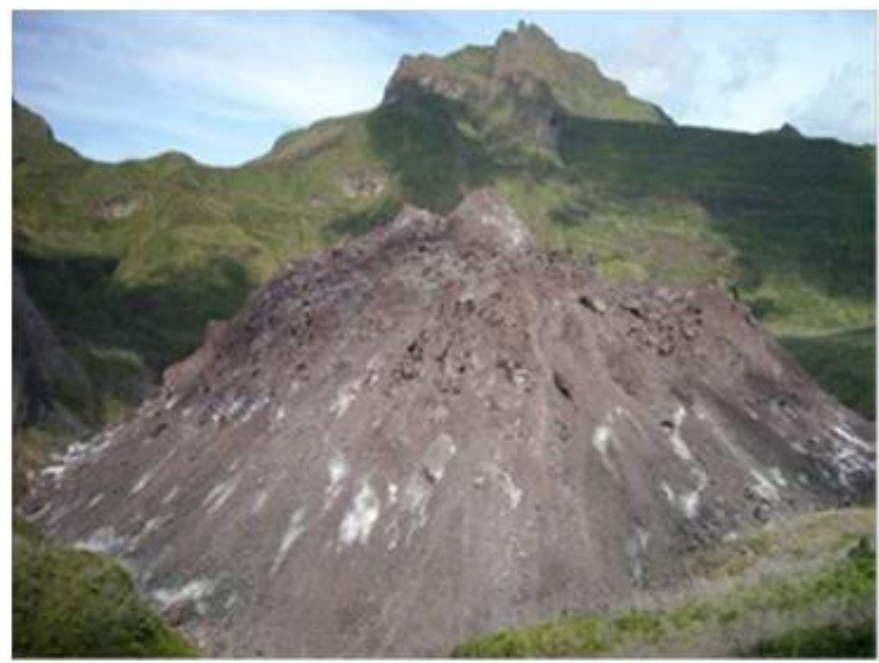

Fig 2:- Lava Dome in Mount Kelud

Before eruption in 2014, the main attraction of Mount Kelud was its lava dome or it's well known as "Anak Gunung Kelud" (Fig 2) and the amazing view around the mountain area [4]. The most common activities that visitors did before eruption happened were taking photo, strolling in the edge of the mountain crater where the lava dome can be found, soaking in a hot spring, enjoying the view, and relaxing in the food stalls in every rest area [4]. 
Besides that, another attraction is the hot spring bath from kelod mountain source (fig. 3). Before eruption, the hot springs baths location was used by visitors as an rea to relax body after walking araound the top of mountain. The existence of a unique attraction from Kelud Mountain makes the location visited by many tourists from Kediri and surrounding areas 16].

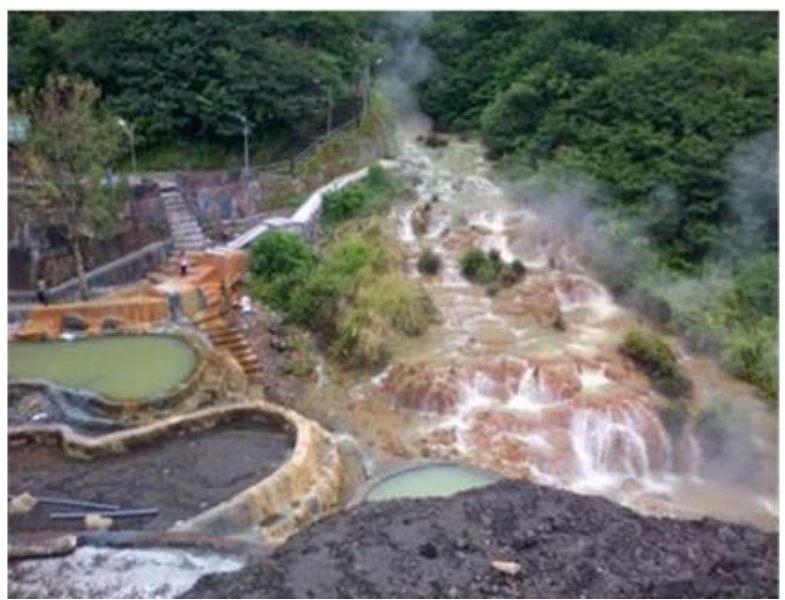

Fig 3:- Hot Springs of Kelud Mountain

This study focuses on the location point of Mount Kelud main attraction (fig 1) and the area around it. Since it was restated as normal in 2014 , the crater of the mountain (fig 4) has been reopened for visitors by limiting the number of the people who can see the place.

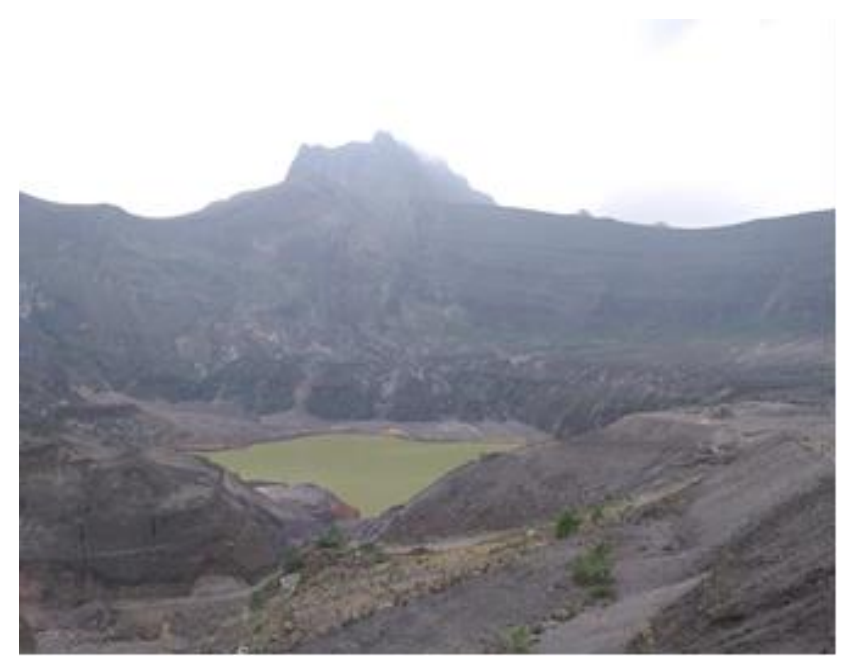

Fig 4:- The Crater of Mount Kelud

Kelud mountain administratively located in Sugihwaras District, under the Kediri Regency government, but geographically located in three regions: Kediri Regency, Blitar, and Malang (fig 1) [6]. For the lower middle class in Kediri Regency, Kelud mountain is a cheap and affordable tourist destination. The ticket fee is only $\mathrm{Rp} \mathrm{10.000.} \mathrm{The}$ visitors also only need to pay $\mathrm{Rp} 25.000$ for the round-trip fee if they want to see the crater by a motorcycle taxi. The motorcycle taxi can help visitors to get to the crater safer since the road is still under construction. The boundary to see the crater for visitors is around 2 kilometers.

The common reason why visitors visit Kelud mountain is because of the high curiosity to see it themselves after the eruption. As one of the dark tourism attractions, this mountain still keeps secondary eruption dangers include cold lava flood and landslide along the edge of the cliff. This condition shows that this tourist destination has a high disaster risk that can thread the safety of the visitors [15]. Meanwhile, the visitors who already came here before 2014 usually want to compare the place before and after the eruption. However, for new visitors who have never been here, the motivation is to see and enjoy the damaged area of the mountain after the explosion. Based on the activity pattern from the visitors while they are here, so the category of the visitors' activity is enjoying natural resources since they want to enjoy the beauty of Mount Kelud even after eruption [3].

If we identified the visitors based on visitors' characteristics of dark tourism, their visit has several motivations: moral, education, and private motivation [13]. Moral motivation from Mount Kelud visitors came from the sympathy towards the eruption victims, and find out about the location to enjoy the view after the disaster happened and talk to the local people who have affected. Education motivation is related to the visitors who want to know from the local people or the tourism manager about how eruption happened. Meanwhile, private motivation is more about self-satisfaction after they visit Mount Kelud as one of the dark tourism sites.

The indirect visitors' interest is based on the tourism product after the disaster happened that Mount Kelud offers. After the eruption in 2014, the facilities for visitors were not as complete as before include the sellers and transportation service. However, in particular points, they still could find rest areas as the attraction of dark tourism. It is needed to use conjoint analysis to know the attraction products that they chose before visiting Mount Kelud. As a result, the most attractive tourism product in that place found from the preference study can be as information sources in developing the are better.

\section{A. Combination of attributes (Stimulli)}

Attributes are variables of study that chosen in the calculation percentage using conjoint analysis [10]. The combination of attributes done by using variables and subvariables as the attribute and level of the attribute is according to the conditions of Mount Kelud. The chosen variables as attributes in the conjoint analysis are tourist attraction, tourism activities, transportation, accommodation types, accommodation facilities, and souvenirs [14]. From these six attributes, they are explained more detail in the point of level of attributes (Table 1). The element of the level of attributes is a specific elaboration of every tourism product in the attribute's points. 
ISSN No:-2456-2165

\begin{tabular}{|c|c|}
\hline Attributes & Level of Attributes \\
\hline Tourist attractions & Natural tourist attraction \\
\hline Tourism activities & Artificial tourist attraction \\
\hline & Enjoying the view \\
\hline & Climbing \\
\hline & Trail adventure \\
\hline & Shopping \\
\hline Accommodation types & Culinary attraction \\
\hline Accommodation facilities & Lodging \\
\hline & Restaurants \\
\hline Transportation & Traditional \\
\hline & Modern \\
\hline & Bus \\
\hline & Car \\
\hline Souvenirs & Motorcycle \\
\hline & Bike \\
\hline & Signature dish \\
\hline
\end{tabular}

Tabel 1:- Atribut dan level atribut analisis konjoin

The process of making the combination of attributes consists of 6 attributes with its 17 level of attributes. The process of making the stimulus or the combination of attributes using SPSS software got 25 different combination of attributes in the tourism site. From 25 results of ID cards, there aren't any similar profile, so the preferences of visitors were really different from each other. Several outputs from the ID cards of combination of attributes can be seen in the ID card 1 until 3 (Table.2,3,4).

The assessing system from the ID card is to give ranks from 1 to 25 or as the total number of the cards without having the same value repetition. After the overall ID cards have been assessed, the next step is to count the importance value and utility value from this tourism attributes.

\begin{tabular}{|c|c|c|c|c|c|c|}
\hline \multicolumn{7}{|c|}{ Profile Number 1 } \\
\hline $\begin{array}{c}\text { Card } \\
\text { ID }\end{array}$ & Tourist attraction & $\begin{array}{c}\text { Tourism } \\
\text { activities }\end{array}$ & $\begin{array}{c}\text { Accommodation } \\
\text { types }\end{array}$ & $\begin{array}{c}\text { Accommodation } \\
\text { facilities }\end{array}$ & Transportation & Souvenirs \\
\hline 1 & $\begin{array}{c}\text { Artificial tourist } \\
\text { attraction }\end{array}$ & Climbing & Restaurants & Traditional & Motorcycles & Souvenirs \\
\hline
\end{tabular}

Table 2:- Card ID 1 Conjoint Analysis Stimulli

\begin{tabular}{|c|c|c|c|c|c|c|}
\hline \multicolumn{9}{|c|}{ Profile Number 2 } \\
\hline Card ID & Tourist attraction & $\begin{array}{c}\text { Tourism } \\
\text { activities }\end{array}$ & $\begin{array}{c}\text { Accommodation } \\
\text { types }\end{array}$ & $\begin{array}{c}\text { Accommodation } \\
\text { facilities }\end{array}$ & Transportation & Souvenirs \\
\hline 2 & $\begin{array}{c}\text { Artificial tourist } \\
\text { attraction }\end{array}$ & $\begin{array}{c}\text { Enjoying } \\
\text { artificial rides }\end{array}$ & Hotel & Luxurious & Bike & Signature dish \\
\hline
\end{tabular}

Table 3:- Card ID 2 Conjoint Analysis Stimulli

\begin{tabular}{|c|c|c|c|c|c|c|}
\hline \multicolumn{9}{|c|}{ Profile Number 2 } \\
\hline Card ID & Tourist attraction & $\begin{array}{c}\text { Tourism } \\
\text { activities }\end{array}$ & $\begin{array}{c}\text { Accommodation } \\
\text { types }\end{array}$ & $\begin{array}{c}\text { Accommodation } \\
\text { facilities }\end{array}$ & Transportation & Souvenirs \\
\hline 3 & $\begin{array}{c}\text { Artificial tourist } \\
\text { attraction }\end{array}$ & $\begin{array}{c}\text { Educational } \\
\text { activities }\end{array}$ & Resort & Standard & Bike & Accessories \\
\hline
\end{tabular}

Table 4:- Card ID 3 Conjoint Analysis Stimulli

\section{B. Utility Value}

The utility value is the margins between factors of value and its constant value from the rank result given by the respondents to the level of attributes $[9,10]$. The positive value shows that the respondents like the attributes and the level presented and vice versa. The more respondents (visitors) like the level of attributes, the bigger the utility value will be. 
ISSN No:-2456-2165

\begin{tabular}{|c|c|c|}
\hline Attributes & Level of attributes & Utility Estimation \\
\hline Tourist attraction & Natural tourist attraction & $-0,480$ \\
\hline & Artificial tourist attraction & 0,480 \\
\hline Tourism activities & Enjoying the view & 2,118 \\
\hline & Climbing & $-0,275$ \\
\hline & Trail adventure & $-0,667$ \\
\hline & Shopping & $-0,913$ \\
\hline & Culinary attraction & $-0,264$ \\
\hline Accommodation types & Lodging & $-0,725$ \\
\hline & Restaurants & 0,725 \\
\hline Accommodation facilities & Traditional & 0,291 \\
\hline Transportation & Modern & $-0,291$ \\
\hline & Bus & $-0,804$ \\
\hline & Car & $-0,330$ \\
\hline & Motorcycle & 1,011 \\
\hline & Bike & 0,123 \\
\hline Souvenirs & Signature dish & $-0,524$ \\
\hline & Accessories & 0,524 \\
\hline
\end{tabular}

Table 5:- The Result of Utility Value

\section{Importance Values}

Impotance values explains the level of it and the tourism attributes presented. The bigger the accumulation value from the overall visitors' choices, the more important and affected the attribute is towards the tourist visit [9].

\begin{tabular}{|c|c|}
\hline \multicolumn{1}{|c|}{ Importance Values } \\
\hline Tourism attractions & 10,363 \\
\hline Tourism activities & 33,165 \\
\hline Accommodation type & 10,136 \\
\hline Accommodation facilities & 10,086 \\
\hline Transportation & 26,855 \\
\hline Souvenirs & 9,394 \\
\hline
\end{tabular}

Table 6:- The Result of Importance Value

Based on the result of the processing between utility value and importance value, the visitors who came to the Mount Kelud was because they were interested in the tourism activities. The result is 33,165 (Table 6) with its attribute to enjoy the natural view in 2,118 (Table 5) is more interesting to do rather than climbing, motor trail, off-road, shopping, and cultural tourism. The second important attribute is transportation 26,855 (Table. 5) with its attribute to ride a motorbike 1,011 (Table. 5) because the visitors can be more enjoyable to look at the view as the attraction of the dark tourism at Mount Kelud. The third attribute is tourism attractions which is 10,363 (Tabel 5) with its level of attribute 0,048 (Table 5) that visitors choose the artificial tourist attraction.

The fourth attribute is the accommodation type with 10,136 (Table 6) with its level attribute to eat in restaurants 0.725 (Table 4) rather than eat in hotels. The reasons are because eating in restaurants offer the signature dish of Mount Kelud which is honey pineapple and also home cooked food. The fifth attribute is the accommodation facilities with 10,086 (Tabel 6). The accommodation facility chosen by the visitors is restaurant with traditional concept with 0,291 (Table 5). The last attribute chosen by the visitors is the souvenirs with 9,394 (Table 6) with its level of attributes which is the seller of accessories with 0,524 (Table 4).

\section{Korelasi}

\begin{tabular}{|c|c|c|}
\hline Correlations & Value & Sig. \\
\hline Pearson's R & 0,807 & 0,000 \\
\hline Kendall's tau & 0,367 & 0,005 \\
\hline
\end{tabular}

Table 7:- The Result of Correlation Value

The result from the calculation of correlation shows the significant value of 0,05 . It can say that this study shows the suitability between expected preferences with the result of the study. With the value of the correlation, it shows that the respondents have high accuracy proven by the significance test. The conclusion from the model processing (utility and importance values) has a strong correlation with the data taken from the correspondent's opinion. So, the point of view from 176 respondents in Mount Kelud is acceptable to describe the visitors' preference in enjoying the attraction of Mount Kelud is one of the dark tourism sites. There are 
many activities to do here, so it makes Kediri Regency as the most valuable attribute that contributed to this calculation. This conclusion supported by the data of the visitors' enthusiasm related to the frequency they visit this place.

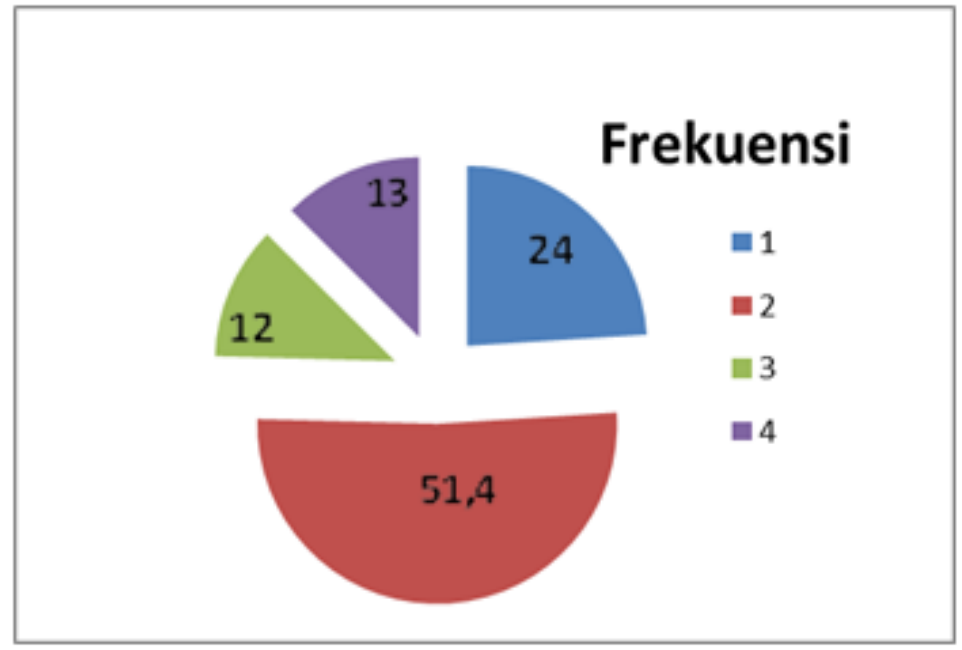

Fig 5:- The Frequency of Visitors' Visit

The first most frequent visit from the visitors who came to Mount Kelud is two times. This visit mostly happens before and after the eruption. Meanwhile, the second most frequent visit is one time for the new visitors who never been here, and they come after the eruption.

\section{CONCLUSION}

A tourist destination can be categorized as a dark tourism site if the place has the remaining disaster history that leads to death and leaves a trace. The location of Mount Kelud is the location that keeps the residual damage and death due to the eruption happened. This remaining eruption turns out to be the main attraction for the visitors shown from the result of conjoint analysis that presents the reasons why visitors come here. The ultimate motivation is to see the beautiful view of Mount Kelud after the eruption, and the rest is to have the morality experience, educational trip, and private experience.

Based on the calculation of the importance value from the tourism attribute, the highest value is in tourism activities that visitors can do in the mountain, so the diversity of activities here becomes the important thing that this place needs to have. The eruption is the main factor for tourists to see the mountain, so they can feel how it was like when it happened and visualized the horrible natural disaster.

Meanwhile, the calculation of the utility value shows that the highest point is the tourism attribute that is the tourists' activities. The level of attributes is to enjoy the natural view. One of the characteristics of dark tourism activities in this study is when the visitors want to see the landscape after eruption happened in Mount Kelud.

\section{REFERENCES}

[1]. Muktaf, Z. M. Wisata Bencana "Sebuah Studi Kasus Lava Tour Gunung Merapi". Jurnal Pariwisata. vol IV, issue 2, pages 2355-6587. 2017

[2]. Afandi, R. L. "Kajian Pengaruh Keberadaan Kawasan Wisata Sangiran Terhadap Aspek Fisik, Aspek Ekonomi, dan Aspek Sosial Masyarakat". Jurnal Teknik PWK. vol. 04, issue 2, pages 282-292. 2015

[3]. Bittner, M. Dark Tourism "Evaluation of Visitors Experience after Visisting Thanatological Tourist Attractions". TURIZAM. vol. 15, issue 4, pages 148158. 2011

[4]. Bachri, S., Utaya, S., Nurdiansyah, F. D., Nurjanah, A. E., Ningtyas, L. W., Purnama, D. S., et al. "Hidup Selaras Bersama Gunung Api". unpublished. pages 978-602-361-072-3.2017

[5]. Devi, S. G. "Pengembangan Pariwisata Gunung Kelud Pasca Erupsi Tahun 2014 (Studi Kasus : Kawasan Wisata Gunung Kelud Kabupaten Kediri )". Jurnal Administrasi Publik. vol. 3, issue 1, pages 2077-2803

[6]. Purwanto, K.Slamet,Mahardi. "Dinamika Spatio Temporal Dampak Erupsi Gunung Kelud di Kabupaten Kediri”. Jurnal Pendidikan Geografi. vol. 22, issue 1, pages 60-72.2017

[7]. Afandi, R. L., \& Ali, M. M. "Kajian Pengaruh Keberadaan Kawasan Wisata Sangiran Terhadap Aspek Fisik, Aspek Ekonomi, dan Aspek Sosial Masyarakat". Jurnal Teknik PWK. vol. 04, issue 2, pages 282-292. 2015

[8]. Al Basya, M. F., Mawardi, M. K., \& Nuralam, I. P. "Analisis Preferensi Konsumen Terhadap Keputusan Menggunakan Jasa Kursus Bahasa Inggris”. Jurnal Administrasi Bisnis. vol. 58, issue 2, pages 197-205. 2018.

[9]. Kembaren, S. C., Bangun, P., \& Sitepu, R. "Preferensi Wisatawan Terhadap Kunjungan Wisata Pulau Samosir Dengan Analisis Konjoin". Saintia Matematika. vol. 02, issue 03, pages 267-275. 2014. 
[10]. Julianisa, R. D., Safitri, D., \& Yasin, H. “Analisis Konjoin Full Profile Dalam Pemilihan Bedak Untuk Mahasiswi Departemen Statistika Universitas Dipobegoro”. Jurnal Gaussian. vol. 4, isue. 4, pages 747-756. 2016.

[11]. Wulandari, E., \& Safriana, D. "Konsep Pengembangan Kota Banda Aceh sebagai Kota Wisata Tsunami”.Arcade Jurnal Arsitektur. vol. 1, issue 1, pages 2580-8613. 2017

[12]. Adhi, A. A., \& Safiri, D. "Analisis Konjoin Full Profile untuk Mengentahui Feature Telepon Selular yang Ideal Dipasarkan Di Kecamatan Banyumanik”. Sewindu Statistika. Prosiding. 2011.

[13]. Bing Jin Yan, e. a. "Investigating The MotivationExperience Relationship in a Dark tourism Space "A Case Study of The Beichuan Earthquake relics, Shina". Tourism Management. vol 53, pages 108-121. 2016

[14]. Sayangbatti, D. P., \& Baiquni.M.. "Motivasi dan Persepsi Wisatawan Tentang Daya Tarik Destinasi Terhadap Minat Kunjungan Kembali di Kota Wisata Batu". Jurnal Nasional Pariwisata. Vol. 5, issue 2, pages 126-136. 2013.

[15]. Rachmawati, T. A., \& Rahmawati, D. “The Resilience Of Tengger People of Dealing With The Mount Bromo Eruption". American Scientific Publishers. vol. 24, issue 12, pages 9423-9428. 2018.

[16]. Suhartini, E., \& Arifiyanti, J. "Daerah Pasca Bencana, Daya Tarik tersendiri bagi Pariwisata Indonesia". Journal of Tourism and Creativity. vol. 2, issue 1, pages 2549-483X. 2018

[17]. Fonseca, A. P., Seabra, C., \& Silva, C. "Dark Tourism Concept, Typologies and Sites". Journal of Tourism Research and Hospitality. pages 1-6. 2016 